\title{
Tax Evasion and Its Consequences on an Emerging Economy: Nigeria as a Focus
}

\author{
Cordelia Onyinyechi Omodero ${ }^{1}$ \\ ${ }^{1}$ Department of Accounting, College of Management Sciences, Michael Okpara University of Agriculture, Umudike, \\ Umuahia, Abia State, Nigeria \\ Correspondence: Cordelia Onyinyechi Omodero, Department of Accounting, College of Management Sciences, \\ Michael Okpara University of Agriculture, Umudike, Umuahia, Abia State, Nigeria.
}

Received: May 27, 2019

doi:10.5430/rwe.v10n3p127
Accepted: September 13, $2019 \quad$ Online Published: September 28, 2019

URL: https://doi.org/10.5430/rwe.v10n3p127

\begin{abstract}
There is a universal understanding that tax evasion is a product of underground economy, however, the two economic scenarios have dissimilar influences on an economy. The effects of tax evasion and underground economy have been examined in this study, in order to establish a statistical evidence of the varying consequences of the two economic circumstances. The study employs secondary form of data ranging from 1991 to 2018 while using ordinary least squares multiple regression technique for the analysis. The findings reveal that tax evasion has a robust significant negative influence on economic growth while underground economy is having a strong and positive significant impact on economic growth of Nigeria. The two independent variables are found to be having very strong relationship with economic growth and are also determining $98.7 \%$ of the variation in the Nominal Gross Domestic Product. In the light of these findings, it is obvious that informal economy and tax evasion have become an integral part of Nigeria's economy doing both harm and good substantially. Therefore, the study recommends more effort on the part of the government to encourage good leadership, formulate policies that will enhance voluntary tax compliance and help the informal sector businesses that are legitimate to become officially registered with little or no cost.
\end{abstract}

Keywords: underground economy, tax evasion, general economic growth, informal sector

JEL Classification codes: E26, H26, O40, 017

\section{Introduction}

Taxation is the most important fiscal instrument the government uses to generate revenue necessary for provision of public services. Bahadur (2018) submits that taxation is a primary tool to raise the revenue required by the government to finance its public expenditure responsibilities. Governments in most developing countries including Nigeria are confronted with the challenge of lack of fund to carry out their social responsibilities due to low tax to GDP ratio caused by high rate of tax evasion. The situation is such that individuals and firms that are engaged in legitimate businesses also hide under underground economy to evade tax with impunity. Tax evasion is a taxpayer's deliberate refusal to comply with his tax obligations through none or partial disclosure of his/her income sources to the relevant tax authorities for proper assessment. According to Bahadur (2018), tax evasion is both illegal and unethical as it decreases government revenue and hinders the overall economic development. It is an act of concealing taxes, through the submission of false documents, false statements or unrealistic information. Modugu and Omoye (2014) posit that tax evasion is the failure to disclose the correct income that should be taxed either through misstatement of facts, falsification of figures, filing of incorrect returns or by misrepresentation of tax liabilities. This is a common economic phenomenon where informal sector activities have dominance as most people struggle to survive through self-employment and entrepreneurship.

Individuals or corporations can purposely refuse to pay taxes by concealing the true state of affairs of their businesses due to high tax rates prevailing in a country and possibly failure of the government to utilize the tax revenue to provide the needed infrastructures. The common form of tax evasion practiced in Nigeria is the deliberate act of failing to file tax returns with the relevant tax authorities in the country (Modugu \& Omoye, 2014). In the same vain, Sosanya (1981) believed that tax evasion in Nigeria is a preferred crime such that armed robbery is perceived as a minority interest. It is seen as a favorite crime because of the high level of unemployment and power 
failure to energize businesses. Enterprises and individuals do not justify the reason to disclose their income and so they remain under the shadow to carry on their businesses in order to evade tax. This is why underground economy and tax evasion work together, although the slight difference is that underground economy increases the gross domestic product of a country, but the resultant effect, which is tax evasion, harms the government because it robs the government of the revenue it should have earned. Underground economy provides an avenue whereby the government suffers financial losses through inevitable and in-built tax evasions (Omodero, 2019). According to Faseun (2001), tax evaders can be prosecuted for criminal offences and the court has the legal backing to subject them to penalties, fines and even imprisonment.

McCann (2006) describes tax evasion as a crime conceived by most countries because it involves stealing government revenue while tax avoidance is the application of all strategies by a tax payer to ensure that he does not pay more tax than the law stipulates. Some countries see tax avoidance as legal, while countries such as India considers it as illegal. Universally, tax evasion is considered as a crime, which means it an unlawful act in a global context. However several reasons have been used to justify tax evasion in our contemporary times, such reasons include: high tax rates, illiteracy, lack of proper awareness, corruption in public offices, lack of adequate training for tax officials, embezzlement of tax revenues, loopholes in the tax laws, inability to interpret complex tax laws, weak legal framework and failure on the part of the judicial system to enforce relevant statutes against tax defaulters (Mughal and Akram, 2012; Adebisi \& Gbegi, 2013; Obafemi, 2014; Onyeka \& Nwankwo, 2016; Folayan \& Adeniyi, 2018). In whichever scenario tax evasion occurs, it is usually harmful to an economy especially the evolving economies, in such a manner that development will keep dwindling. The purpose of this study is to determine the effect of tax evasion caused by informal sector activities on the economy and also to provide an empirical evidence that underground economy does not seem to be harmful to an economy as a result the legal activities deserve recognition and formalization for the government to earn tax revenue.

\section{Theoretical Review}

\subsection{Benefit Received Theory}

Benefit Received Theory of taxation established by Wicksell (1896) and Lindahl (1919) is the theory anchoring this study. The theory centers on the efficacy of tax revenue in providing public services and supports government at all levels (federal, state and local) to generate revenue from a multiplicity of sources in order to sufficiently deliver public goods and services to the public. The theory adopts an exchange relationship between the tax-payers and the government in the sense that the governments collect taxes from both individuals and companies for the purpose of providing basic amenities such as water, housing, education, health care services, security, transportation and communication among others (Omodero \& Dandago, 2019). The government has the obligation to provide basic facilities to the populace while the public is expected to respond by paying taxes that are commensurate with the benefits derived (Bhartia, 2009).

According to Anyanfo (1996), taxes should be imposed based on the benefits received from the government. The theory stresses that individuals and companies ought to pay taxes depending on their ability to pay and based on the amount of benefits accruing to them. In other words, individuals and companies that receive higher benefits pay higher taxes. However, this theory has not been fully applied in any circumstance because the government has also failed to measure the benefits received by individuals and firms with the services rendered (Ahuja, 2012). If the benefits received theory is applied in practice, the issue of tax evasion will not be witnessed in Nigeria because the participants in underground economy activities that are spread across the country would have found reasons to formalize their businesses and voluntarily comply with their tax obligations. Due to the government failure to provide the basic amenities required for businesses to flourish and expand, taxpayers in Nigeria found tax evasion and avoidance as an ethical practice (Ibadin \& Eiya, 2013).

\subsection{Principle of Tax Morale}

The principle of tax morale states that citizens have the moral right to pay their taxes as part of their civic responsibility to the government. According to Ukaj (2014), good governance increases citizens' trust in public institutions and enhances their resistance to tax evasion and avoidance. As good citizens, they are meant to abide by the principle of tax morale which enjoins companies and individuals to pay taxes as their own contribution to the society and to maintain a healthy relationship with the government. Citizens that practices tax morale realize the fact that payment of taxes is their moral right and does not require the government to coerce them before compliance is achieved. Aruba (2010) submits that the citizens' confidence in their government crumbles the moment they recognize the government system is corrupt. The implication is that the same citizens will intentionally choose to evade tax or devise strategies to avoid tax payment due to the unlawful and corrupt acts of government officials. 
According to Modugu and Omoye (2014) the tax evasion under this scenario will be accomplished through willful act of omission or commission which includes: failure to submit tax returns to the relevant tax authorities, refusal to settle tax liabilities, deliberate omission of items in the returns, underestimation of income and overstatement of expenditures, refusal to answer tax queries, recording of fictitious transactions, demanding illegitimate reliefs, misstatement of items in the returns among others. This is because citizens have been forced to ignore the act of tax morale that should have been a natural practice due to the ill behavior of government tax officials who even sometimes collect bribe to encourage tax avoidance and evasion. Therefore, the ability of the government to educate citizens on the benefits of paying taxes as well as using the tax revenue for proper service delivery will help to discourage tax avoidance and evasion (Adebisi \& Gbegi, 2013).

\subsection{Empirical Review}

\subsubsection{Foreign Studies}

Bahadur (2018) investigated the effect of tax evasion on total tax revenue and economic growth in Nepal. The study employed the research tools of correlation and linear regression analysis in order to establish the relationship existing between tax evasion and the dependent variables (total tax revenue and GDP) as well as its effects for a period of 9 years. The results showed that tax evasion had an inverse relationship with Nepal's economic growth and tax revenue. The study further found that tax evasion had a negative impact on total tax revenue and Nepal's GDP.

Carlos and Lars (2018) applied a theoretical model and dynamic OLG model of tax evasion to assess the relationship between tax evasion and economic development. The study found evidence that a higher tax rate increases aggregate tax evasion and the number of tax evaders. At the same time, GDP per capita had a positive correlation with tax morale while evaded taxes over GDP reduced when there was growth in a country.

Konstantinos, Pantelis and Vangelis (2018) used a standard endogenous growth model with public capital accumulation enriched with tax evasion to provide empirical evidence on the relationship between aggregate output growth, announced tax rate and tax monitoring expenses for a set of 32 OECD countries for a period covering 2000-2007. The results of the study indicated that high announced tax rates above the elasticity of public capital and excess expenses on tax auditing as means of reducing tax evasion were not effective due to recession. Using panel data, Mehrara and Farahani (2016) also examined the effects of tax evasion and tax revenues on economic stabilities of 29 OECD countries from 1990 to 2013. The study firstly used the monetary approach to estimate the tax evasion index before investigating the effects of tax evasion and tax revenues on economic stability of the selected countries. The results indicated that tax evasion led to economic instability while increased tax revenues had the tendency of improving the economic situation of the 29 OECD countries.

Mughal and Akram (2012) considered the causes of tax avoidance and evasion by using primary data gathered through administering of questionnaires using descriptive statistical tools, the results indicated that all variables representing the causes of tax evasion and avoidance in Pakistan were accurate and there was a 100\% positive relationship among the study variables.

\subsubsection{Domestic Studies}

Adebisi and Gbegi (2013) employed both primary and secondary data to examine the effect of tax avoidance and tax evasion on personal income tax administration in Nigeria. The study found a direct and positive relationship between tax avoidance, tax evasion, tax rates and personal income tax administration in Nigeria. The findings further unraveled the fact that proper use of tax revenue to provide public goods and services could improve revenue collection and discourage tax avoidance and evasion in Nigeria. Wambi and Hanga (2013) employed survey approach by administering questionnaire and measuring the data generated with simple percentage and use of majority opinion. The results showed that informal sectors in Kano were not reporting their incomes to the tax authority and as a result there was no tax compliance. The study also discovered that tax compliance had a strong correlation with proper use of tax revenue to provide public services as well as public awareness of citizens' obligation to pay tax and the benefits to be derived.

Ibadin and Eiya (2013) studied tax evasion and avoidance behavior of the self-employed Nigerians. The study sampled the opinions of Nigerians in selected geo-political zones and states using ethical views, educational attainment, mode of tax administration, religion and cultural practices and how each variable affected the decision of the self-employed Nigerian to evade and avoid tax payment. The results from the regression analysis indicated that the respondents deemed tax evasion to be ethical especially within the context of the situation they found themselves. The issue of deeming tax evasion to be ethical should be attributed to lack of good governance in Nigeria. The issue is such that individuals struggle to provide power and water for themselves in order to run their businesses, in such a 
scenario tax evasion should be deemed ethical and applauded because there is no proper leadership in the country. It is adjudged that there is no commensurate benefit emanating from the tax revenue the government receives, considering the level of insecurity and unconducive business environment. Sometimes some businesses run at loss due to high overhead cost caused by lack of infrastructures in the country and so payment of tax is not justified. If government fulfills its obligations to the citizens in terms of public service delivery following the tax revenue it receives, businesses will thrive and people will willingly comply with their tax obligations without hiding under underground economy to evade tax. However tax evasion is a criminal act and it is never ethical. For something to be ethical, it must be morally right and professionally acceptable. Thus, tax evasion is morally wrong and professionally prohibited by all standards.

Modugu and Omoye (2014) employed primary data to assess the personal income tax evasion in Edo State Nigeria. A total number of 160 questionnaires were administered to certain persons which comprised accountants, businessmen, contractors, architects, doctors, lawyers as well as the Federal Inland Revenue Service officers in Benin City. The study found a positive relationship between the high tax rate and tax evasion. The result of the study further revealed that taxpayers' relationship with tax authority as well as weak penalties had a significant impact on tax evasion. The study suggested among others a more cordial relationship between tax administrators and payers in order to encourage voluntary compliance. Obafemi (2014) did a similar study using survey method whereby a well-structured questionnaire was administered to 150 Nigerians consisting majorly of tax payers and tax evaders. The findings revealed that tax evasion and avoidance had a negative effect on economic growth and development. The study also found that tax evasion and avoidance had been a product of lack of good governance and unpatriotic acts on the part of the citizens. The study recommended promotion of good governance and tax morale by tax payers.

Akinleye and Ogunmakin (2016) carried out a research on the effect of tax avoidance on government budget implementation in the Southwest of Nigeria. With the use of simple random sampling, the states selected for the study include: Ekiti, Ogun, Ondo and Osun while the secondary data used for the analysis were collected on capital gains tax (CGT), pay-as-you-earn (PAYE), Value Added Tax (VAT) and Withholding tax (WHT). The findings showed that $61 \%$ of the anticipated incomes of the states were not met due to tax avoidance practiced in the states. Thus, the study established that tax avoidance led to poor performance of the government budgets in the selected states, thereby reducing the expected economic growth and development that would have been achieved.

Al-Mustapha and Hamza (2016) used a survey approach whereby a questionnaire instrument was employed to investigate the determinants of informal sector tax evasion in Sokoto Metropolis. The responses from the survey indicated that fiscal factors as well as tax administrative factors among others were the major causes of tax evasion. Onyeka and Nwankwo (2016) assessed the effect of tax evasion and avoidance on Nigeria's economic growth from 1999 to 2012 using Ordinary Least Squares Regression (OLS) techniques. The result showed that both the tax evasion and avoidance had a significant negative impact on economic growth of Nigeria.

Folayan and Adeniyi (2018) studied the effects of tax evasion on government revenue generation in Oyo State using both primary and secondary form of data which covered a period from 2011 to 2016 . The study also employed descriptive and inferential statistical tools for analysis and the findings indicated that expected revenue between 2011 and 2016 were not met. Therefore, the findings revealed that tax evasion caused by the revenue loss which implied that tax evasion had a negative influence on government internally revenue generation in Oyo State.

\subsection{Gap in Literature}

Considering the studies that have been reviewed, there is need to comparatively and holistically investigate the impacts of tax evasion and underground economy on an emerging economy such as Nigeria. The question is, does the government have the moral justification to stop underground economy or fight tax evasion emanating from the shadow economy activities. This study is planned to provide an answer to this complex question and to provide empirical evidences that will motivate the policy makers to encourage good governance in order to minimize informal economy and consequently eliminate tax avoidance and evasion affecting the growth of the economy.

\section{Methodology}

\subsection{Research Design}

In order to achieve the purpose of this study, shadow economy transaction approach of measurement was used to extract the value of the underground economy embedded in the nominal gross domestic product (see Appendix 1). The transaction approach uses data gathered on the overall transactions in the economy which represent both the official and unofficial Nominal GDP, thus the estimated size of the shadow economy is subtracted from the total Nominal GDP. In Nigeria, the Nominal GDP consists of contributions from both official activities and unofficial activities (shadow economy). In the same manner, tax evasion was determined using the Multiple Indicator Multiple 
Cause (MIMIC) approach which draws attention to the various reasons for the emergence of underground economy as well as the resultant effects. This approach uses both the visible and the discreet variables causing shadow economy and the resultant effects of the informal sector (Abdih \& Medina, 2016, Schneider, 2010, Vuletin, 2009). Therefore, tax evasion is identified as one of the product of underground economy (see the computation in Appendix 1). Here the research adopted the econometric analysis techniques of ordinary least squares (OLS) multiple regression technique to provide an empirical evidence on the impact of tax evasion and underground economy on the economy.

\subsection{Types and Sources of Data Collection}

The study made use of secondary form of data because the purpose of this research is to produce an empirical evidence in this area of study. The secondary form of data for the variables employed in this study covered a period from 1991 to 2018. The dependent variable is the Nominal GDP while the independent variables were underground economy and tax evasion. All the variables were expressed in billions of Naira (local currency) and were collected from the Central Bank of Nigeria Statistical Bulletin and International Monetary Fund. The level of significance chosen for this study is $5 \%$, thus the individual result of the variables will be significant at $5 \%$. The multicollinearity test is done with Variance-Inflatory Factor (VIF) and the index value is expected to be below the value of 10. The VIF of an independent variable above 10 indicates the presence of multicollinearity.

\subsection{Model Specification}

The practical and econometric association between the dependent variable and the explanatory variables can be observed in the following equation:

$$
\begin{gathered}
\text { NGDP }=\mathrm{f}(\mathrm{UNDE}, \mathrm{TXVN}) \\
\mathrm{NGDP}=\beta_{0}+\beta_{1} \text { UNDE }+\beta_{2} \text { TXVN }+\mu
\end{gathered}
$$

Where: NGDP $=$ Nominal Gross Domestic Product; UNDE $=$ Underground economy; TXVN $=$ Tax Evasion; $\beta_{0}=$ Constant; $\beta_{1}-\beta_{2}=$ Regression coefficients; $\mu=$ Error term.

On the a priori, we expect; $\beta_{1}<0, \beta_{2}<0$.

\section{Data Analysis and Interpretation}

Table 1. Model summary of results

\begin{tabular}{lrrrrr}
\hline Model & R & R Square & $\begin{array}{c}\text { Adjusted R } \\
\text { Square }\end{array}$ & $\begin{array}{c}\text { Std. Error of the } \\
\text { Estimate }\end{array}$ & $\begin{array}{c}\text { Durbin-Wat } \\
\text { son }\end{array}$ \\
\hline 1 & .994 & .987 & .986 & 4564.84856 & 2.241 \\
\hline
\end{tabular}

a. Predictors: (Constant), UNDE, TXVN

b. Dependent Variable: NGDP

Source: Author's computation, 2019.

From table 1 above, the correlation value is $99.4 \%$ showing the existence of a strong and positive relationship between the dependent variable (NGDP) and the independent variables (UNDE and TXVN). Similarly, the R Square value is $98.7 \%$ which is equally very strong signifying that underground economy and tax evasion determine a very high degree of variability in NGDP. Thus, the remaining $1.3 \%$ is linked with other variables that did not appear in the model. This result is a pointer that Nigeria's economy is fraught with these two common economic elements (underground economy and tax evasion practices). The Durbin-Watson is 2.2 which suggests the absence of a serial correlation.

Table 2. ANOVA test results

\begin{tabular}{lrrrcc}
\hline Model & \multicolumn{1}{c}{ Sum of Squares } & \multicolumn{1}{c}{ df } & \multicolumn{1}{c}{ Mean Square } & F & \multicolumn{1}{c}{ Sig. } \\
\hline Regression & 40057886839.036 & 2 & 20028943419.518 & 961.181 & .000 \\
Residual & 520946060.394 & 25 & 20837842.416 & & \\
Total & 40578832899.430 & 27 & & & \\
\hline
\end{tabular}

a. Dependent Variable: NGDP 


\section{b. Predictors: (Constant), UNDE, TXVN}

Source: Author's computation, 2019.

Table 2 above displays the result of the F-statistic which is 961.181 with a p-value of $0.000<0.05$. This result shows that the predictor variables (TXVN and UNDE) jointly and positively influence economic growth (NGDP) in Nigeria. The result is statistically significant specifying the appropriateness of the model.

Table 3. Regression correlations and coefficients

\begin{tabular}{|c|c|c|c|c|c|c|c|}
\hline \multirow[t]{2}{*}{ Model } & \multicolumn{2}{|c|}{$\begin{array}{l}\text { Unstandardized } \\
\text { Coefficients }\end{array}$} & \multirow{2}{*}{$\begin{array}{c}\text { Standardized } \\
\text { Coefficients }\end{array}$} & \multirow[t]{2}{*}{$\mathrm{T}$} & \multirow[t]{2}{*}{ Sig. } & \multicolumn{2}{|c|}{$\begin{array}{l}\text { Collinearity } \\
\text { Statistics }\end{array}$} \\
\hline & B & Std. Error & & & & Tolerance & VIF \\
\hline (Constant) & 1104.004 & 1188.827 & & .929 & .362 & & \\
\hline $1 \mathrm{TXVN}$ & -5.702 & 1.141 & -.314 & -4.995 & .000 & .130 & 7.715 \\
\hline UNDE & 2.232 & .110 & 1.280 & 20.343 & .000 & .130 & 7.715 \\
\hline
\end{tabular}

\section{a. Dependent Variable: NGDP}

Source: Author's computation, 2019.

Table 3 above shows the test for multicollinearity using Variance-Inflatory Factor (VIF) and the individual performance of the study independent variables measured by the t-statistics. Multicollinearity exists when two or more independent variables have a robust relationship indicating sturdy intersection in evaluating the same element. Multiple regression model assumes that explanatory variables are not interrelated (Australian Property Institute, 2015:487) and so multicollinearity test is carried out to establish that there is no strong correlation existing between the independent variables used in a study. Therefore, multicollinearity test is done using the VIF which shows the speed with which variances of a variable increase when there is a presence of multicollinearity (Gujarati \& Porter, 2009:340). The common rule is that, when VIF index exceeds the value of 10, the individual variable concerned is highly collinear, while the VIF value below 10 indicates absence of collinearity in the variables. Thus, the VIF column in this study on table 3 above shows the absence of multicollinearity in all the independent variables employed because the values (7.715) are all below 10 .

Table 3 also indicates the t-test results of the predictor variables used in this study. TXVN t-statistic is -4.995 while the p-value is $0.000<0.05$. This result implies that tax evasion (TXVN) has a strong significant negative impact on economic growth (NGDP). This result is consistent with the findings of (Onyea \& Nwankwo, 2016; Bahadur, 2018; Folayan \& Adeniyi, 2018). UNDE t-statistic is 20.343 while the p-value is $0.000<0.05$. The result of the underground economy indicates a robust significant positive influence on NGDP. This is a statistical proof that informal economy positively affects the economy despite its informality and the unofficial activities that are being carried out in the sector.

\section{Conclusion and Recommendation}

\subsection{Conclusion}

The statistical evidence provided by this study leads to a conclusion that tax evasion and underground economy form an integral part of the Nigeria's economy. The R Square has a value of $98.7 \%$ which is very close to $100 \%$, in other words, the economy is booming with informal sector activities which is at the same time robbing the government of legitimate income. The major question here is whether the government is making substantial effort to curtail the underground economy activities without throwing people out of jobs. The consequence of underground economy on government's revenue is very much unfavourable but the participants do not stand to be blamed because the government fails in their functions. No wonder, in the study of Ibadin and Eiya (2013) on different geo-political zones and states in Nigeria, the respondents affirmed that tax evasion was ethical to them, because they do not feel the effect of good governance in their own nation.

\subsection{Recommendations}

- First of all, the study is recommending good leadership and governance. Respect is earned and not forced, meaning for citizens to voluntarily comply with tax payments to the government without any form of 
coercion and attempts for further tax evasion and avoidance, the government has the duty to command their respect through good works as expected by a good government. The leaders owe citizens an obligation to provide adequate public goods and services with the public funds and not to misappropriate those funds.

- Public awareness is highly necessary, where there is proper knowledge at the disposal of the people, they will understand that tax payment is their moral right and civic responsibility. In other words the practice of tax morality will be a lifestyle and willingly taxes will be paid without the effort of the government to force compliance.

- Tax incentives will be a motivational tool for taxpayers. For instance, if a taxpayer is promised one year tax leave for complying for like five years continuously, the individual or firm will ensure that tax payment for those five years will be judiciously complied with. There are other tax incentives that can also give more room for those in the informal sector to show up. For example, increasing the personal income tax reliefs, capital allowance reliefs and loss reliefs.

- Free registration of businesses is another instrument that is capable of reducing underground economy activities. If banks are able to get people opening accounts with them without much struggle, then formalization of the informal sector activities is simple especially those of them that are legitimate. Removal of registration cost, VAT penalties and late returns penalties will do the magic. This is because, after calculating the cost of formalizing a business in Nigeria, some people will decide to remain informal and keep evading the tax.

- Imposing restriction on patronage. Some informal sector activities enjoy high level of patronage from registered companies and even government corporations. Some are major contractors to companies and public sector organizations through the back door. Following the large market they have even while unregistered, formalization becomes a fiction and a good waste of time and resources. Therefore, the government should consider dealing with those that patronize them in order to reduce their market and bring them to a point where they will find registering of their businesses as an ideal step to take.

- The study is recommending more works by scholars and upcoming researchers in the form of update until the policy makers will find tax evasion in Nigeria as an economic and a social menace that requires urgent and concerted effort to overcome for the betterment of the country.

\section{Acknowledgement}

The author acknowledges the effort and useful contributions of the anonymous reviewers and editors of Research in World Economy. I thank all the data providers (CBN, FIRS and IMF) and scholars whose works provided insight and direction to this study.

\section{References}

Abdih, Y., \& Medina, L. (2016). The informal economy in the Caucasus and Central Asia: Size And determinants. In A. Sauka, F. Schneider, \& C. C. Williams (Eds.), Entrepreneurship and the Shadow Economy (2016). Edward Elgar Publishing Inc.

Adebisi, J. F., \& Gbegi, D. O. (2013). Effect of tax avoidance and tax evasion on personal income Tax administration in Nigeria. American Journal of Humanities and Social Sciences, 1(3), 125-134. https://doi.org/10.11634/232907811301328

Ahuja, H. L. (2012). Modern Economics. Analytical study of Microeconomics; Macroeconomics; Money Banking; and Public Finance; International Economics; Economics of Growth and Development. $16^{\text {th }}$ Revised edition, published by S. Chand \& Company Ltd.

Akinleye, G. T., \& Ogunmakin, A. A. (2016). The effect of tax avoidance on government budget Implementation in Southwest Nigeria. International Journal of Accounting and Taxation, 4(1), 53-68. https://doi.org/10.15640/ijat.v4n/a3

AL-Mustapha, A. A., \& Hamza, M. S. (2016). Determinants of informal sector tax evasion in Sokoto Metropolis. Igbinedion University Journal of Accounting, 2, 127-147.

Anyanfo, A. M. O. (1996). Public Finance in a developing economy: The Nigerian case. Department of Banking and Finance, University of Nigeria, Enugu Campus, Enugu.

Australian Property Institute. (2015). The valuation of real estate (2nd ed.). Canberra, Australia: Appraisal Institute. 
Bahadur, J. K. C. (2018). Tax evasion in Nepal: An Inquiry. Pravaha Journal, 2018, 83-95. Retrieved from https://www.nepjol.info/index.php/pravaha/article/view/20228/16621

Bhartia, H. L. (2009). Public Finance (14th ed.). Vikas Publishing House PVT Ltd., New Delhi.

Carlos, B., \& Lars, K. (2018). Tax evasion, social norms, and economic growth. Journal of Public Economic Theory, 21(2), 332-346. https://doi.org/10.1111/jpet.12346

Folayan, D. O., \& Adeniyi, A. G. (2018). Effects of tax evasion on government revenue generation In Oyo State, Nigeria. European Journal of Accounting, Auditing and Finance Research, 6(1), 76-89.

Faseun, L. A. (2001). Tax planning: Lagos tax. The Newsletter of CITN - Lagos District Society, 1, 6-9.

Gujarati, D. N., \& Porter, D. C. (2009). Basic ecometrics. New York: McGraw-Hill Education.

Ibadin, P. O., \& Eiya, O. (2013). Tax evasion and avoidance behavior of the self-employed Nigerians. European Journal of Business and Management, 5(6), 1-16.

Konstantinos, C., Pantelis, K., \& Vangelis, T. (2018). Tax evasion, tax monitoring expenses and Economic growth: An empirical analysis in OECD countries. Empirical Economics, 2018, 1-16. https://doi.org/10.1007/s00181-018-1441-8

Lindahl, E. (1919). Just Taxation - A positive solution (E. Henderson, trans.). In R. A. Musgrave, \& A. T. Peacock (Eds.), Classics in the Theory of Public Finance. Macmillan.

McCann, H. (2006). Offshore Finance. Cambridge: Cambridge University Press.

Mehrara, M., \& Farahani, Y. G. (2016). The study of the effects of tax evasion and tax revenues on Economic stabilities in OECD countries. World Scientific News, 33(2016), 43-55.

Modugu, K. P., \& Omoye, A. S. (2014). An appraisal of personal income tax evasion in Nigeria. Asian Economic and Financial Review, 4(1), 33-40.

Mughal, M. M., \& Akram, M. (2012). Reasons of tax avoidance and tax evasion: Reflections from Pakistan. Journal of Economics and Behavioural Studies, 4(4), 217-222.

Obafemi, F. J. (2014). An empirical study of tax evasion and tax avoidance: A critical issue in Nigeria economic development. Journal of Economics and Sustainable Development, 5(18), 22-26.

Omodero, C. O. (2019). The Financial and Economic implications of underground economy: The Nigerian $\begin{array}{lllll}\text { Perspective. Academic Journal of Interdisciplinary Studies, } & 8(2), & \text { 155-167. }\end{array}$ https://doi.org/10.2478/ajis-2019-0027.

Omodero, C. O., \& Dandago, K. I. (2019). Tax revenue and public service delivery: Evidence From Nigeria. International Journal of Financial Research, 10(2), 82-91. https://doi.org/10.5430/ijfr.v10n2p82.

Onyeka, V. N., \& Nwankwo, C. (2016). The effect of tax evasion and avoidance on Nigeria's Economic growth. European Journal of Business and Management, 8(24), 158-166.

Schneider, F. (2010). The influence of public institutions on the shadow economy: An empirical Investigation for OECD Countries. European Journal of Law and Economics, 6(3), 441-468.

Sosanya, S. O. A. (1981). Taxation reform in Nigeria. Lagos.

Ukaj, S. D. (2014). Tax evasion and the impact on economic growth. Acta Universitatis Danubius, Economica, 10(6), 18-32.

Wambai, U. S. K., \& Hanga, B. Y. (2013). Taxation and Societal development in Nigeria: Tackling Kano's hidden economy. International Journal of Academic Research in Business and Social Sciences, 3(3), 113-125.

Wicksell, K. (1896). Finanztheoretische Untersuchungen. Gustav Fisher: Jena. 
Appendix 1. Calculation of underground economy (UNDE) and tax evasion (TXVN) from 1991-2018

\begin{tabular}{|c|c|c|c|c|c|c|}
\hline YEAR & NGDP & UNDERGROUND & UNDE & FME & TRVE & TXVN \\
\hline & (UNDE+FME) & ECONOMY & $\%$ OF NGDP & (NGDP-UNDE) & NON-OIL & $($ TRVE/FME)*UNDE \\
\hline & & (UNDE) & & & REVENUE & \\
\hline & N'BILLIONS & $\%$ OF GDP & N'BILLIONS & N'BILLIONS & N'BILLIONS & N'BILLIONS \\
\hline 1991 & 596.04 & 56.95 & 339.39 & 256.65 & 18.33 & 24.24 \\
\hline 1992 & 909.8 & 58.17 & 529.23 & 380.57 & 26.38 & 36.68 \\
\hline 1993 & $1,259.07$ & 58.82 & 740.58 & 518.49 & 30.67 & 43.81 \\
\hline 1994 & $1,762.81$ & 66.61 & $1,174.21$ & 588.60 & 41.72 & 83.23 \\
\hline 1995 & $2,895.20$ & 62.21 & $1,801.10$ & $1,094.10$ & 135.44 & 222.96 \\
\hline 1996 & $3,779.13$ & 61.09 & $2,308.67$ & $1,470.46$ & 114.81 & 180.26 \\
\hline 1997 & $4,111.64$ & 60.69 & $2,495.35$ & $1,616.29$ & 166 & 256.28 \\
\hline 1998 & $4,588.99$ & 62.33 & $2,860.32$ & $1,728.67$ & 139.3 & 230.49 \\
\hline 1999 & $5,307.36$ & 59.87 & $3,177.52$ & $2,129.84$ & 224.77 & 335.33 \\
\hline 2000 & $6,897.48$ & 57.9 & $3,993.64$ & $2,903.84$ & 314.48 & 432.50 \\
\hline 2001 & $8,134.14$ & 57.64 & $4,688.52$ & $3,445.62$ & 903.46 & $1,229.35$ \\
\hline 2002 & $11,332.25$ & 59.93 & $6,791.42$ & $4,540.83$ & 500.99 & 749.30 \\
\hline 2003 & $13,301.56$ & 57.19 & $7,607.16$ & $5,694.40$ & 500.82 & 669.05 \\
\hline 2004 & $17,321.30$ & 56.72 & $9,824.64$ & $7,496.66$ & 565.7 & 741.37 \\
\hline 2005 & $22,269.98$ & 55.84 & $12,435.56$ & $9,834.42$ & 785.1 & 992.75 \\
\hline 2006 & $28,662.47$ & 51.95 & $14,890.15$ & $13,772.32$ & 677.54 & 732.53 \\
\hline 2007 & $32,995.38$ & 54.96 & $18,134.26$ & $14,861.12$ & $1,264.60$ & $1,543.13$ \\
\hline 2008 & $39,157.88$ & 53.06 & $20,777.17$ & $18,380.71$ & $1,336.00$ & $1,510.19$ \\
\hline 2009 & $44,285.56$ & 53.98 & $23,905.35$ & $20,380.21$ & $1,652.65$ & $1,938.51$ \\
\hline 2010 & $54,612.26$ & 52.8 & $28,835.27$ & $25,776.99$ & $1,907.58$ & $2,133.90$ \\
\hline 2011 & 62,980 & 51.51 & $32,441.00$ & $30,539.00$ & $2,237.88$ & $2,377.26$ \\
\hline 2012 & $71,713.94$ & 51.56 & $36,975.71$ & $34,738.23$ & $2,628.78$ & $2,798.10$ \\
\hline 2013 & $80,092.56$ & 51.7 & $41,407.85$ & $38,684.71$ & $2,950.56$ & $3,158.26$ \\
\hline 2014 & $89,043.62$ & 50.64 & $45,091.69$ & $43,951.93$ & $3,275.03$ & $3,359.96$ \\
\hline 2015 & $94,144.96$ & 52.49 & $49,416.69$ & $44,728.27$ & $3,082.41$ & $3,405.51$ \\
\hline 2016 & $101,489.49$ & 48.37 & $49,090.47$ & $52,399.02$ & $2,985.13$ & $2,796.64$ \\
\hline 2017 & $113,711.63$ & 65.01 & $73,923.93$ & $39,787.70$ & $3,207.90$ & $5,960.15$ \\
\hline 2018 & $116,099.57$ & 65.04 & $75,511.16$ & $40,588.41$ & $5,300.00$ & $9,860.18$ \\
\hline TOTAL & $1,033,456.07$ & & $571,168.01$ & $462,288.06$ & $36,974.03$ & $47,801.92$ \\
\hline
\end{tabular}

SOURCES OF DATA: CBN STATISTICAL BULLETIN 2017 EDITION, FIRS 2018 REPORT, IMF WORKING PAPER 2018 AND AUTHOR'S COMPUTATION, 2019. 